\title{
Solid cancer as second malignancy in primary hematological cancer after conventional Treatment- A single institutional study
}

\author{
Sulav Sapkota ${ }^{1^{*}}$, Mona Priyadarshini ${ }^{2}$, Radheshyam Naik ${ }^{3}$ \\ ${ }^{1}$ Assistant professor, ${ }^{2}$ Consultant, ${ }^{3} \mathrm{HOD},{ }^{1,3}$ Dept. of Medical Oncology, Dept. of Gynae-Oncology, ${ }^{\mathbf{1 , 2}}$ Birat Medical College \\ Teaching Hospital, Tankisinuwari, Nepal, ${ }^{3} \mathrm{HCG}$ Hospital, Bangalore, Karnataka, India
}

\section{*Corresponding Author: Sulav Sapkota}

Email: dr.sulavsapkota@yahoo.com

\begin{abstract}
Aims: To study the clinico-pathological features of solid cancer as second malignancy in primary hematological cancer after conventional treatment.

Objectives: To study the demographics, treatment and prognosis of solid cancer as second malignancy.

Materials and Methods: It's a retrospective study conducted over period of nine years in our centre using computer based data base and medical records as the data source from the department of medical oncology and hematology.

Result: Total 5 patients were diagnosed with primary hematological cancers who underwent conventional treatment and later developed second malignancy. Majority of cases were female patient (60\%) with mean age of 49.8 years (range 27-72 yrs) diagnosed as primary hematological cancer with advanced stage. Out of 5 patients, only 4 patients (80\%) developed solid cancers which included 2 breast cancers, 1 cervix cancer and 1 head and neck cancer. Of these four patients, three could be salvaged with conventional treatment while one was lost to follow up.

Conclusion: Solid cancers are one of the rare second malignancies that might occur after conventional treatment in hematological cancers which should be regularly monitored.
\end{abstract}

Keywords: Solid cancer, Treatment, Hematological cancer.

\section{Introduction}

As per the literature, the incidence of double primary malignancy is rare $^{1,2}$ of which one of the earliest statistical analyses was done by Bugher in $1934 .{ }^{3}$ With recent treatment modalities, even the hematological cancer patients are surviving much longer with risk to develop new primary, which might or might not be related to the treatment of earlier. This concept especially holds true to chronic hematological malignancies like multiple myeloma, chronic myeloid leukemia, lymphoma etc which will be having risk of developing second malignancies in future. The aim at this study was to report our observations about incidence of solid cancers as second malignancy in primary hematological cancer treated with conventional treatment. Double primary malignancies could be divided into two categories, depending on the time interval between tumor diagnoses. ${ }^{4}$ Synchronous malignancies are second tumors that occur either simultaneously or within 6 months after the first malignancy while metachronous malignancies are secondary tumors that develop after 6 months, or even more than that from the first malignacy. The criteria we have used for the diagnosis of double primary malignancies were primarily given by Warren and Gates. $^{5}$
Although the mechanism involved in the development of second primary cancer is poorly understood, factors like heredity, constitution, environmental, immunological factors, infective, radiological and cytotoxic treatments have been implicated. ${ }^{6,7}$ The current treatment results of patients with solid second malignancies re-main challenging. The poor response relates to a larger proportion of patients presenting with old age, high-risk cytogenetics, refractoriness to treatment and increase in co-morbidities that prevents them from the conventional treatment. Long-term survival with multiple primaries is variable and is influenced by cancer type and stage at diagnosis. ${ }^{8}$

\section{Materials and Methods}

This is a retrospective study conducted from Jan 2010 to Jan 2019 in the department of Medical Oncology and Hematology in our HCG hospital which is a tertiary care cancer center. The study was initiated using computer based database and medical records as the data source. Solid cancer as second malignancy was defined as a clinically symptomatic patient with histo-pathological diagnosis. 


\section{Inclusion criteria}

Double primary malignancies need to be proved histological.

First primary cancer needs to be hematological cancer who has undergone conventional treatment.

\section{Exclusion criteria}

\section{Hematological cancer as second malignancy.}

A study pro-forma was created, which included patient identification, primary diagnosis, stage,histological types, treatment received, date of second malignancy,second malignancy diagnosis, conditioning regimen, date of transplant etc. Patient's disease status till the last follow up was recorded along with the prognosis. After the collection of reports statistical analysis was done using. Patients who were lost to follow up after therapy were censored as alive at their last follow up. Descriptive statistics was used for analysis of demographic variables and disease characteristics.

\section{Result}

\section{Patients characteristics (Table 1)}

Total 28 patients were diagnosed with dual malignancy during the study period out of which only 5 patients were having blood cancer as a primary first cancer with conventional treatment as per the inclusion criteria. Majority of cases were female patient $(60 \%)$ with mean age of 49.8 years (range 27-72yrs) diagnosed as primary hematological cancer with advanced stage. Multiple myeloma and lymphoma ( $40 \%$ each) were the common hematological cancers followed by chronic myeloid leukemia(20\%). 2 cases $(40 \%)$ were having family history of cancer. $80 \%$ patients had received chemotherapy while $40 \%$ patients had received radiotherapy in conventional treatment. Only 1 patient $(20 \%)$ had undergone autologous stem cell transplantation for primary hematological cancer. Post treatment, $60 \%$ patients were in clinical remission(CR) while $40 \%$ were in partial remission. Mean conversion time of primary hematological cancer to second malignancy was about 55.4 months (range 1-132 months). Out of 5 patients, only 4 patients (80\%) developed second solid malignancy while 1patient developed second hematological malignancy. None of the patients had history of exposure to radiation before the diagnosis of hematological cancer.

\section{Solid cancer as second Primary characteristics (Table 2)}

Out of 5 patients, 4 patients $(80 \%)$ developed second solid malignancies which included 2 breast cancers, 1 cervix cancer and 1 head and neck cancer. The individual characteristic features have been depicted in table $2.50 \%$ of the cases were diagnosed as early stage (stage 1 and 2) while $50 \%$ cases were diagnosed as advanced stage (stage 3 and 4). 3 out of 4 patients $(75 \%)$ were female patients with metachronous malignancy. All of them had undergone complete conventional treatment of which $50 \%$ cases were in clinical remission post treatment while $50 \%$ cases were stable disease. The mean conversion time of primary hematological malignancy to second solid malignancy was about 62.5 months(range 1132 months). Genomic tests were not done in any patients in our study. Of these four patients, three could be salvaged with conventional treatment while one was lost to follow up. The mean survival duration of first hematological malignancy till last follow up was about 73.75 months (range 5-155 months) while the mean survival duration of second solid malignancy till last to follow up was about 11.25 months (range 423

months).

Table1: Characteristics of the patients with dual malignancy in hematological cancer as first malignancy

\begin{tabular}{|l|c|c|}
\hline Characteristics & No. of patients (n=5) & Percentage \\
\hline Mean Age & 49.8 & - \\
\hline Male & 2 & 40 \\
\hline Female & 3 & 60 \\
\hline Underlying Primary Hematological Cancers & & \\
\hline Multiple myeloma & 2 & 40 \\
\hline Chronic myeloid leukemia & 1 & 20 \\
\hline Lymphoma & 2 & 40 \\
\hline Family History & 2 & 40 \\
\hline Co-morbidity & 1 & 20 \\
\hline Serology & - & - \\
\hline Habits (Tobacco/Smoking) & 1 & 20 \\
\hline Treatment Received & & \\
\hline
\end{tabular}




\begin{tabular}{|l|c|c|}
\hline Chemotherapy & 4 & 80 \\
\hline Radiotherapy & 2 & 40 \\
\hline Transplantation Received & 1 & 20 \\
\hline Post Treatment status & 3 & 60 \\
\hline CR & 2 & 40 \\
\hline PR & 55.4 & - \\
\hline Mean conversion time to second malignancy (in months ) & 4 & 80 \\
\hline Metachronous second malignancy & 5 & 100 \\
\hline Conventional treatment received for second malignancy & 2 & 40 \\
\hline Most common Second malignancy (Breast) & 4 & 80 \\
\hline Solid malignancy as second malignancy & 1 & 20 \\
\hline Hematological malignancy as second malignancy & 2 & 40 \\
\hline Post treatment status Clinical Remision & 3 & 60 \\
\hline Post treatment status Stable Disease & 3 & 60 \\
\hline Status of patient (Alive) & 2 & 40 \\
\hline Lost to follow up & & \\
\hline
\end{tabular}

Table 2: Characteristics of solid cancer cases( second malignancy) in primary hematological cancer.

\begin{tabular}{|c|c|c|c|c|}
\hline Characteristics & Case 1 & Case 2 & Case 3 & Case 4 \\
\hline Age & 47 & 63 & 72 & 40 \\
\hline Sex & Female & Female & Male & Female \\
\hline Family History & Nil & $\begin{array}{l}\text { Mother had } \\
\text { cancer rectum. }\end{array}$ & Nil & $\begin{array}{c}\text { Sister had } \\
\text { gynecological } \\
\text { cancer }\end{array}$ \\
\hline Co-morbidity & Nil & Nil & HTN & Nil \\
\hline Serology & Nil & Nil & Nil & Nil \\
\hline Habits & Nil & Nil & Smoker & Nil \\
\hline Primary Diagnosis & Multiple Myeloma & $\begin{array}{l}\text { Chronic Myeloid } \\
\text { Leukemia }\end{array}$ & Multiple Myeloma & $\begin{array}{c}\text { Lymphoma } \\
\text { stomach(MALT) }\end{array}$ \\
\hline Staging & stage III & $\begin{array}{c}\text { Accelerated } \\
\text { phase }\end{array}$ & stage IIA & Stage IIE \\
\hline $\begin{array}{l}\text { Chemotherapy } \\
\text { /Target therapy } \\
\text { Received/RT }\end{array}$ & $\begin{array}{l}\text { Bortezomib, Dexona } \\
\text { regimen 4cycles }\end{array}$ & Imatinib & $\begin{array}{l}\text { Bortezomib,Doxorubucin, } \\
\text { Dexona regimen } 4 \text { cycles }\end{array}$ & $\begin{array}{c}\text { R CHOP 8 Cycles, } \\
\text { RT }\end{array}$ \\
\hline $\begin{array}{c}\text { Transplantation } \\
\text { Received } \\
\end{array}$ & -planned & - & Autologous Transplant & - \\
\hline Post treatment status & Progressive & $\begin{array}{l}\text { Clinical } \\
\text { remission }\end{array}$ & Clinical remission & Clinical remission \\
\hline $\begin{array}{l}\text { Time duration for } \\
\text { second malignancy }\end{array}$ & 24 months & 1 months & 93 months & 132 months \\
\hline Second Malignancy & $\begin{array}{c}\text { IDC Breast- Left, } \\
\text { ER,PR -ve,Her } 2 \\
+ \text { +ve }\end{array}$ & $\begin{array}{c}\text { Ca Cervix, } \\
\text { Squamous cell } \\
\text { carcinoma }\end{array}$ & $\begin{array}{l}\text { SCC left supraglottis, } \\
\text { Squamous cell carcinoma }\end{array}$ & $\begin{array}{l}\text { IDC Breat- Right, } \\
\text { Triple positive }\end{array}$ \\
\hline Stage & pT2No- Stage I & Stage IIB & cT2N2bMx Stage IVA & $\begin{array}{l}\text { pT2N2aM0- stage } \\
\text { IIIA }\end{array}$ \\
\hline $\begin{array}{l}\text { Type of second } \\
\text { malignancy }\end{array}$ & Metachronous & Synchronous & Metachronous & Metachronous \\
\hline Genomic Test & - & - & - & - \\
\hline Treatment Received & $\begin{array}{c}\text { Conventional } \\
\text { treatment }\end{array}$ & $\begin{array}{c}\text { Conventional } \\
\text { treatment }\end{array}$ & Conventional Treatment & $\begin{array}{c}\text { Conventional } \\
\text { Treatment }\end{array}$ \\
\hline Surgery & $\begin{array}{l}\text { Modified radical } \\
\text { mastectomy. }\end{array}$ & - & - & $\begin{array}{l}\text { Lumpectomy+ } \\
\text { SLND }\end{array}$ \\
\hline $\begin{array}{l}\text { Chemotherapy/ } \\
\text { Hormonal }\end{array}$ & $\begin{array}{c}\text { Neoadjuvant } \\
\text { docetaxel,carboplati } \\
\text { n,herceptin }\end{array}$ & - & Carboplatin & $\begin{array}{c}\text { Adjuvant } \\
\text { docetaxel,carboplati } \\
\text { n,herceptin } \\
\text { Hormonal. }\end{array}$ \\
\hline
\end{tabular}




\begin{tabular}{|c|c|c|c|c|}
\hline Radiotherapy & - & $\begin{array}{c}\text { EBRT } \\
50.4 \mathrm{gy} / 28 \#-- \\
\mathrm{ICBT}\end{array}$ & $\begin{array}{c}\text { CTRT with Carboplatin. } \\
\text { 60gy/33\# }\end{array}$ & $50 \mathrm{gy} / 25 \#$ \\
\hline $\begin{array}{l}\text { Status of second } \\
\text { malignancy }\end{array}$ & Stable Disease & $\begin{array}{l}\text { Clinical } \\
\text { remission }\end{array}$ & Stable Disease & Clinical remission \\
\hline Status of patient & Alive & Alive & - & Alive \\
\hline $\begin{array}{l}\text { Survival duration } \\
\text { from primary } \\
\text { diagnosis }\end{array}$ & 36 months & 5 months & 99 months & 155 months \\
\hline $\begin{array}{l}\text { Survival duration } \\
\text { from second } \\
\text { malignancy. }\end{array}$ & 12 months & 4 months & 6 months & 23 months \\
\hline Attributable factor & - & - & $\begin{array}{c}\text { ?doxorubicin. } \\
\text { ?conditioning regimen }\end{array}$ & $\begin{array}{c}\text { ?cyclophosphamide, } \\
\text { doxorubicin }\end{array}$ \\
\hline Follow up & $\begin{array}{l}\text { completed CPD } \\
\text { regimen for MM. } \\
\text { planned for } \\
\text { transplant. } \\
\text { On follow up. On } \\
\text { Tab Imatinib }\end{array}$ & $\begin{array}{l}\text { On follow up. } \\
\text { On Tab Imatinib. }\end{array}$ & Lost to follow up & On follow up \\
\hline
\end{tabular}

\section{Discussion}

The occurrence of multiple primary malignancies, which was thought to be a rare occurrence is being diagnosed more frequently which might be due to an increased awareness of possibility of a second malignancy, the higher use and sensitivity of diagnostic methods. As patients with primary cancer tend to undergo regular follow-up, this could lead to earlier diagnosis of second malignancies at curable stages. ${ }^{9}$ It is an established fact that individuals that suffered from malignancy exhibit a 14-20\% higher risk of subsequent primary malignancies. ${ }^{10}$ Cancer survivors that develop a second malignancy have a higher risk of dying and experience a worsening in their qualities of life. ${ }^{11}$

As per our study during the nine years period, we had total 5 dual malignancies cases of hematological cancer as first primary cancer with conventional treatment of which metachronous cancers were more common than the synchronous cancers. Majority of the cases were female patients with multiple myeloma and lymphoma as first primary cancer with advanced stages. They had undergone conventional treatment and were in clinical remission for almost five years post treatment. Out of 5 cases, only 1 case had undergone autologous transplant for primary hematological cancer. Out of 5 primary hematological cancers, only 4 patients developed second solid cancers with mean conversion time of 62.5 months of which the most common were breast cancer. All the solid cancer patients had undergone conventional treatment and three patients were salvaged till the last follow up with mean survival duration of 11.25 months from the diagnosis. Hence in our study solid cancer as second malignancy was found rare and treatable clinically with better prognosis.

The strength of this study lies in the fact that solid cancer as a second malignancy in primary hematological cancer treated with conventional therapy is very rare in incidence which we have studied over a period of nine years. However, this is a retrospective analysis which has its inherent limitation of missing data and lack of follow up. Secondly, we have a very less number of patients data and lack of genomic studies, hence we couldn't analyze on etiopathogenesis of solid cancer as second malignancy in depth.

\section{Conclusion}

Solid cancers are one of the rare second malignancies that might occur after conventional treatment of hematological cancers which should be regularly monitored. Treatment of solid cancer as second malignancy is particularly challenging on our setting as it requires a well developed tertiary cancer care centre.

Compliance with Ethical Standards

\section{Source of funding}

None.

\section{Conflict of Interest}

The Author(s) declare(s) no conflict of interest. 


\section{Ethical approval}

All the procedures performed in studies involving human participants were in accordance with the ethical standards of the institutional and/or research committee.

\section{Consent}

Informed consent was obtained from all patients included in the study.

\section{References}

1. Morgenfeld EL, Tognelli GF, Deza E, Santillan D, Ares S, Morgenfeld E, et al. Synchronous and metachronous second (ST) and third (TT) primary tumors (PT) in a large patient population. Proc ASCO 2003; 22:3152.

2. Hulikal N, Ray S, Thomas J, Fernandes DJ. Second primary malignant neoplasms: A clinicopathological analysis from a cancer centre in India. Asian Pac J Cancer Prev 2012;13(12):6087-91. [PubMed]

3. Bugher JC. The probability of the chance occurrence of multiple malignant neoplasms. Am J Cancer 1934;21(4):2309.

4. Moertel CG; Multiple primary malignant neoplasms: Historical perspectives. Cancer 1977;40(4):1786-92.
5. Warren S, Gates O; Multiple primary malignant tumors: A survey of the literature and statistical study. Am J Cancer 1932; 16:1358-414.

6. Hemminki K, Boffetta P, Multiple primary cancers as clues to environmental and heritable causes of cancer and mechanisms of carcinogenesis. IARC Sci Publ 2004:28997.

7. Koubková L, Hrstka R, Dobes P, Vojtesek B, Vyzula R, Second primary cancers - causes, incidence and the future. Klin Onkol 2014;27:11-7

8. Vogt A, Schmid S, Heinimann K, Frick H, Herrmann C, Cerny $\mathrm{T}$. et al Multiple primary tumours: challenges and approaches, a review. ESMO Open 2017; 2(2): e000172

9. Luciani A, Balducci L. Multiple primary malignancies. Semin Oncol 2004;31:264-73.

10. [Soerjomataram I, Coebergh JW. Epidemiolgy of multiple primary cancers. Method Mol Biol 2009;471:85-105.

11. Soerjomataram I, Louwman MW, Ribot JG, Roukema JA, Coebergh JW. An overview of prognostic factors for long term survivors of breast cancer. Breast Cancer Res Treat 2008;107:309-30.

How to cite: Sapkota S, Priyadarshini M, Naik R. Solid cancer as second malignancy in primary hematological cancer after conventional Treatment- A single institutional study. IP Int $J$ Med Paediatr Oncol 2020;6(1):27-31. 